\title{
Kamu ve Özel Sektör Ar-Ge Faaliyetleri ve İktisadi Büyüme: OECD Örneği
}

\author{
DOI: 10.26466/opus.581612
}

\author{
$*$

\section{Yusuf Bayraktutan* - Fatma Kethudaoğlu ${ }^{* *}$} \\ * Prof. Dr., Kocaeli Üniversitesi, İktisadi ve İdari Bilimler Fakültesi, İzmit / Kocaeli / Türkiye \\ E-Posta: ybayraktutan@kocaeli.edu.tr \\ ORCID: 0000-0002-4453-3701 \\ ** Dr., TÜBITTAK Savunma Sanayii Araştırma ve Geliştirme Enstitüsü, Mamak / Ankara / Türkiye \\ E-Posta: f.turgut41@gmail.com \\ ORCID: $\underline{0000-0003-4464-4943}$
}

\section{Öz}

İnovasyonun önemli bir bileşeni olarak araştırma-geliştirme (ar-ge), verimliliği arttırmakta ve iktisadi büyümeye katkı sağlamaktadır. Ülkeler, yetenek ve bilgi stoğunu arttırmak için özel kesim ar-ge faaliyetlerini desteklemekte; kamu kesimi araştırma kapasitesini geliştirmek üzere ulusal araştırma sistemleri oluşturmakta; üniversiteler, mobilite programlar ve eğitim ürünleri üzerinde durmaktadır. Özel, kamu ve yükseköğrenim ar-ge faaliyetlerinin büyüme üzerindeki etkileri farklılaşmaktadır. Teorik literatür, inovasyon ve ekonomik büyüme arasında pozitif yönlü bir bağlantı olduğunu göstermektedir. Bu çalışma, ar-ge'ye dayalı büyüme modellerinin hipotezlerini harcama kaynağ̆ ayrımında test etmektedir. OECD üyesi 29 ülkenin 1996-2015 verileriyle özel, kamu ve yükseköğrenim kesimlerinin araştırmageliştirme harcamalarının büyüme üzerindeki etkilerini panel veri yöntemiyle araştırmayı amaçlayan bu çalışma, temel kavramsal ve kuramsal tanıtımı takiben dünyada ve OECD üyelerinde ar-ge verilerini yorumlamakta; ilgili literatürü özetleyerek model ve bulgulara dayalı değerlendirmeler sunmaktadır. Analiz sonuçları, ar-ge harcamalarını iktisadi büyümeyi pozitif olarak etkilediŭini göstermekte; büyüme üzerindeki etkisi bakımından yükseköğrenim ar-ge harcamaları ve özel kesim öne çıkmaktadır.

Anahtar Kelimeler: Ar-Ge; Büyüme, İçsel Büyüme, OECD 


\title{
R\&D Activities of Public and Private Sector and Economic Growth: The Case of OECD
}

\begin{abstract}
As an important component of innovation, research and development (RED) raises productivity and leads to economic growth. Countries support private sector RED activities to increase the capacity and knowledge base; develop national research systems to consolidate public sector research infrastructure; developing university capacities to create mobility programs and educational products. The effects of private, public and higher education sectors' RED activities on economic growth are different. The theoretical literature shows that there is a positive link between innovation and economic growth. This study aims to test the hypothesis of growth models based on RED in terms of expenditure sources. This study, which aims to investigate the affects of business, government and higher education expenditures on RED on economic growth for the 29 OECD countries by using the annual data for the period of 1996-2015, following the basic conceptual and theoretical introduction, interprets the RE D data of world and OECD members; summarizes the relevant literatüre, and presents the evaluations based on analysis of two models and their findings. The results of the analysis show that RED expenditures in this field affect economic growth positively; higher education and private sector are at the forefront in terms of the effect on growth.
\end{abstract}

Keywords: $\quad R \& D$, Growth, Endogenous Growth, OECD. 


\section{Giriş}

Araştırma-geliştirme (ar-ge) faaliyetleri, teknolojik gelişme yoluyla rekabet gücü, dış ticaret ve büyüme performansını etkilemekte; milli gelirden ar-ge faaliyetlerine ayrılan payın farklılaşması, ülkeleri iktisaden ayrıştırmaktadır. Ar-ge ve yenilik çalışmalarına daha fazla kaynak ayıran gelişmiş ülkeler (GÜ), yeni ürünler/yöntemler geliştirmekte; düşük birim maliyetler, artan kalite ve rekabet gücüyle büyüme performansını desteklemektedir.

Ar-ge kavramı, uzun dönem büyümeyi açıklamaya yönelen teorik çabalara paralel şekilde teknolojik gelişme ve inovasyonun bir ölçütü olarak literatürdeki yerini almıştır. Ar-ge, bilgi, süreç ve üretimde somutlaşarak mevcut fiziki ve beşeri kaynakların etkin kullanımına sebep olan ve yeni teknolojileri ortaya çıkaran faaliyetlerdir (Bassanini, and Scarpetta, 2001, s.15). OECD tarafından standart bir ölçü belirlemek amacıyla hazırlanan Frascati Klavuzu'nda, "bilgi stoğunun artmasina ve bunun yeni uygulamalar tasarlamak üzere kullanılmasına ilişkin sistematik ve yaratıcı çalışmalar" ar-ge olarak adlandirılmaktadır (OECD, 1993, s.29). Bilimsel ve teknolojik alanlardaki belirsizlikleri ortadan kaldırmak amacıyla yeni teknik bilgilerin elde edilmesi, yeni üretim yöntem ve süreçlerinin geliştirilmesi, tasarım çalışmaları ile yeni teknik ve prototiplerin üretilmesi, bir ürünün maliyet düşürücü, kalite veya performansını yükseltici yeni teknik ve teknolojilerin araştırılması ile özgün tasarıma dayanan yazılım faaliyetleri bu kapsamdadır. Ar-ge sonucu yeni bir ürün ortaya çıkabileceği gibi, mevcut ürünleri daha düşük maliyetle üretme olanağı da doğabilmektedir. Ar-ge faaliyeti sonucunda elde edilen ürünler, pazarlanabilir hale geldiğinde ar-ge projesi tamamlanmaktadır.

İçsel büyümenin kaynaklarını açıklamaya yönelen iki yaklaşımdan söz etmek mümkündür. Paul Romer (1986) ve Robert Emerson Lucas (1988) modellerinin yer aldığı ilk gruba göre, üretim sürecinde ekonomi genelinde ortaya çıkan ölçeğe göre artan getiriler, dışsal tasarruflar yoluyla büyümeye yol açmakta; üretimde pozitif dışsallıklar nedeniyle herhangi bir teknolojik gelişme olmasa da uzun dönemde büyüme gerçekleşebilmektedir. Schumpeterci geleneğe sahip ikinci yaklaşımda ise, yenilik ve teknolojik gelişmenin büyüme üzerindeki rolü dikkate alınmaktadır. İlk 
grupta yer alan modellere göre, teknolojik gelişme, sadece diğer faaliyetlerin rastlantısal bir ürünü iken Romer (1990), Gene M. Grossman ve Elhanan Helpman (1991) ile Philippe Aghon ve Peter Howitt (1992) tarafından geliştirilen ikinci grup modellere göre, verimlilik artışı sağlayan fikirler veya yeni ürünler üreten ar-ge, özel sektör tarafından gerçekleştirilen bir faaliyet olarak modele dahil edilmektedir. Bu modellerde, teknolojik gelişmenin temelinde kar güdüsü ve ar-ge yer almaktadır. Ar-ge faaliyetleri sonucunda, yeni sermaye malları üretiminde kullanılabilen ve rekabetçi olmayan fikirler ortaya çıkmakta; yeni teknolojiye dayalı yatırımlar ile eğitim ve bilgi ilintili faaliyetlerdeki artış, işgücü başına düşen sermayenin azalan getirilerini ortadan kaldırmaktadır. Bu durumda, ar-ge ve teknolojik gelişme, sınırlı kaynaklardan daha fazla katma değer üretimi ve uzun vadede büyümeyi olanaklı kılmaktadır.

Özel, kamu ve yükseköğrenim kesimlerince yürütülen ar-ge faaliyetleri ile büyüme arasında pozitif bir etkileşim bulunduğu düşüncesinden yola çıkarak bu çalışmada önce ar-ge ve teknolojik gelişmenin iktisadi düşüncedeki yerini yansıtan teorik birikime yer verilmiş; ikinci olarak, OECD ülkelerinin teknoloji ve ar-ge politikaları değerlendirilmiştir. Bu doğrultuda, "ar-ge yoğunluğu ile kişi başına gelirin büyüme oranı arasında pozitif ve istatistiksel olarak anlamlı bir ilişki vardır" ana hipotezi sınanmış; ar-ge, fon kaynağına göre özel kesim, kamu kesimi ve yükseköğrenim harcamaları şeklinde ele alınmış; ar-ge harcamalarının gayrisafi yurt içi hasıla (GSYİH) üzerindeki etkileri fon kaynağı ayırdında değerlendirilmiştir. Analiz, verilerine ulaşılabilen 29 OECD ülkesi ve 1996-2015 dönemi ile sınırlandırılmış ve Panel Veri Regresyon Modeli kullanılmıştır.

\section{Kuramsal Çerçeve}

Adam Smith (1776, s. 272-276), iktisadi büyümeyi imalat sanayisinde işbölümü, yeni makinelerin kullanımı ve makineleri kullananların uzmanlaşma becerileri üzerinde durarak açıklamış; David Ricardo (1817, s.8-28), dışsal bir faktör olarak değerlendirdiği teknolojik gelişmenin iktisadi büyümeyi artıracağına, ancak işsizliğe yol açarak olumsuz etkilerinin de oluşabileceğine değinmiştir. Karl Marx (2003, s.315) ise, kapitalist sistemin varlığını, ayrıntılı ele alınan teknolojik gelişme ile oluşan yeni ürün ve üre- 
tim süreçlerine dayandırmış; sermaye mallarında yeniliklere önem atfederek, teknolojinin üretkenliği arttırdığına işaret etmiştir. Joseph Schumpeter (2003, s.21), mevcut mal ve endüstrilerin yenilikler yoluyla sürekli değiştiğini; teknolojik gelişmenin bu anlamda ekonomi genelinde yaratıcı bir yıkıma yol açtığını savunmaktadır. Kenneth Arrow (1962, s.157), üretim miktarı arttıkça uzmanlaşma ve işbaşında öğrenme sonucu maliyetlerin düşerek yeni ürünlerin ortaya çıktığını ve mevcut ürün kalitesinde iyileşmeler sağlandığını ileri sürmektedir.

Klasik büyüme teorilerinde, sınırları sermaye birikimine dayandırılan teknolojik gelişme, üretimin doğrudan/içsel belirleyicisi olarak görülmemektedir. Sermaye birikimi için tasarruf ve yatırımlara vurgu yapılmakta; nüfus artışının teknolojik gelişmenin pozitif etkilerini ortadan kaldırdığ1 düşünülmektedir. 1800'lerin ortalarından itibaren Avrupa'da yüksek nüfus artışına rağmen kişi başına GSYİH artmış; bu durum ar-ge ve teknolojik gelişmeyi dışsal kabul eden klasik teorinin sorgulanmasına neden olmuştur.

Klasik iktisatçlar, büyümeyi emek ve uzmanlaşma odaklı ele alırken, 1980'li yıllardan itibaren "içsel teknolojik gelişme" ve "ar-ge" ile ilintili teoriler geliştirilmiştir. Dünyada nüfus ve gelir artışına paralel olarak artan talep, teknolojik gelişme ile bütünleşik sanayileşmeyi hızlandırmış; haberleşme ve bilgiye erişimin gelişen konumu, yenilik odaklı yaklaşımları gerekli kılmıştır. Ar-ge, iktisadi büyüme sürecinin ayrılmaz bir parçası haline gelmiş ve büyüme literatüründe sıklıkla anılır olmuştur. Neoklasik büyüme modelleri, büyümenin içsel bir belirleyicisi olarak sermaye birikimine odaklanmış; öngörülemeyen değişmeler, "Solowgil artık" şeklinde adlandırılan toplam faktör verimliliğine atfedilmiştir (Tang, $\mathrm{Hu}$, and Lin, 2005, s.3). Solow'a (1956, s.70) göre, verimlilik, sermaye birikimindeki artışlardan kaynaklanmaktadır. Sermaye birikiminin azalan getirileri, teknolojik ilerleme oranını aşan bir büyümeye izin vermemektedir. Neoklasik modelde, sürdürülebilir büyüme ve sürekli artan yaşam standartları, yalnızca teknolojik gelişme ile açıklanmakta; ancak teknoloji, klasik teoride olduğu gibi sabit ve dişsal olarak ele alınmaktadır. Diğer yandan, yüksek tasarruf oranı, yalnızca yeni bir dengeye erişilinceye kadar büyümeyi sağlayabilmektedir. Buna göre modelde, sermayenin işgücünden daha hızlı arttığı bir ekonomide, faiz oranlarının düşeceği ve düşük gelire sahip ülkelerin daha hızlı büyüyerek yüksek gelirli ülkelere yakınsayacağı 
öngörülmektedir. Büyüme için teknolojik gelişmenin gerekli olduğu vurgulanmış; teknolojik gelişmenin nasıl sağlanabileceği konusuna herhangi bir açıklama getirilmemiştir.

1980'lerden itibaren, mikroiktisadi temeller üzerinde daha fazla durulmaya başlanmış; matematik ve ekonometri modelleme sürecinde artarak yerini alırken geleneksel analizlerde kapsanmayan faktörler dikkate alınabilmiştir (Fine, 2000, s.245). Bu gelişmelerin katkısıyla ivme bulan İçsel Büyüme Teorisi, büyümenin, ekonominin kendi dinamikleri içinde birtakım faktörlerin etkileşimiyle içsel olarak belirlediğini ileri sürmektedir (Romer, 1994, s.3). Robert Barro, Lucas ve Romer'in öncülüğünde geliştirilen içsel büyüme modellerinde, beşeri sermaye, ar-ge faaliyetleri ve teknolojik gelişme, büyümenin içsel belirleyicileri olarak ele alınmış; sermayenin azalan getirilerini ortadan kaldıran bilgi ilintili yatırımların, çıktıdaki uzun dönemli artışın kaynağı olduğu savunulmuştur. Romer (1986), iktisadi büyümeyi içsel faktörler olarak kabul ettiği ar-ge faaliyetleri ile teknolojik yeniliklere dayandırmış; Lucas (1988), ar-ge harcamaları ve beşeri sermayenin teknoloji üzerindeki etkilerini ortaya koymaya çalışmıştır. Teknolojik gelişmenin, piyasa teşviklerini yakından izleyen iktisadi karar birimlerinin girişimleriyle ortaya çıktığ Lucas modelinde, geleneksel büyüme modellerindeki pasif devlet anlayışı terk edilerek, ar-ge harcamaları ve eğitimin gelişmesini teşvik eden, mülkiyet haklarını koruyan, piyasaları düzenleyen bir kamu politikası önerilmiştir.

Kamu harcamalarının büyüme sürecinde katalizör etkisi yarattığını ileri süren Barro (1990), büyümeyi fon kaynağı ayrımında irdelemiştir. Analizin başlangıç noktası, özel kesimin, üretkenlik artışına katkı sağlayacak kamu mallarını üretmede yetersiz kalacağıdır. Barro (1990) modelinde, ölçeğe göre sabit getiri sağlayan üretim fonksiyonunda kamu kesimi dikkate alınmış; kamu harcamaları, tasarruf oranı ve büyüme arasındaki ilişki araştırılmıştır. Kamu kesimince ar-ge çalışmalarının teşvik edilmesi sonucu, eğitim, sağlık, altyapı yatırımları, vb şeklinde sunulan kamu hizmetleri, sosyal anlamda en uygun düzeyde olacaktır. Kamu harcamalarının GSYİH'ye oranı ile piyasalardaki aksaklıklar büyüme üzerinde olumsuz; siyasi istikrar ise, olumlu etki doğurmaktadır. Kamu harcamalarının büyümeyi olumsuz yönde etkilemesi, temelde vergilendirme nedeniyle özel tasarrufların azalmasına bağlanmaktadır. Çalışmalarda, 
kamu yatırımları/GSYİH oranının büyüme üzerinde istatistiksel olarak anlamlı bir etkisi saptanamamıştır.

Gelişmiş ve gelişmekte olan ülkeler arasındaki büyüme farklılıklarını açıklamaya yönelen içsel büyüme literatürü, büyümeyi, tanımlanan model ve dolayısıyla sistem dışındaki etkenlere bağlayan neoklasik büyüme yaklaşımından ayrışmaktadır. İçsel büyüme modelleri ile yenilikçilerin monopol karları, bilgi, beşeri sermaye, ar-ge, finansal yenilikler, kamu kesimi ve piyasa yapıları, ülkeler arasındaki gelir farklılıkları için birer açıklayıcı olarak sunulmuştur. Romer (1986, s.1005), birey veya firmaların yeni fikir arayışlarını büyüme modeline dahil ederek teknolojik gelişmeyi içselleştirmiştir. Yenilikçiler, verimlilik, ürün kalitesi, pazar payı ve karlılıklarını artırmak amacıyla ar-ge faaliyetleri yürütmekte; yenilikler sayesinde elde edilen kar, ar-ge harcamalarını finanse etmektedir. Romer'e (1990, s.72) göre, büyümenin temel dinamiği olarak teknolojik gelişme, karar birimlerini sermaye birikimine teşvik etmekte; teknolojik yenilikler ile işçi başına sermaye yatırımındaki artışlar, işgücü başına üretimi arttırmaktadır. Teknolojik gelişme, büyük oranda piyasa teşviklerini yakından izleyen firmaların bilinçli girişimlerine bağlı olarak içsel şekilde ortaya çıkmaktadır. Üretim sürecinde bilgi ile diğer girdiler arasında bir ayrım bulunmakta; yeni bir bilgi setini oluşturma maliyeti tek sefere mahsus olup tekrar kullanımı ek bir maliyet doğurmamaktadır. Romer' in (1990), yayılmalar ve monopolistik unsurları ar-ge sektöründe bir araya getirmesi, büyüme literatürüne önemli bir katkıdır (Rensman, 1996, s.35). Yalnızca ar-ge ile oluşturulan bir model, kamu harcamaları, yaparak öğrenme ya da beşeri sermayeyi esas alanlarla benzer sonuçlar ortaya koymaktadır.

Grossman ve Helpman (1991), büyümeyi dış ticaret ve dişa açıklık ile ilişkilendirmektedir. Beşeri sermaye stoğu nispeten büyük olan ülkeler, ticaret ortaklarına göre daha fazla ar-ge faaliyetinde bulunmakta ve yenilikçi mal üretebilmektedir. Ülkelerin büyüme oranları farklılık göstermesine rağmen, reel tüketim artış oranları ve refah düzeyleri aynı olabilir. Bunun temel nedeni, uluslararası ticaret kanalının yenilikçi ürünlerin tamamına ulaşma olanağı sağlamasıdır. Ar-ge yatırımlarına yeterli kaynak ayıramayan ülkeler, dışa açıklık oranlarını artırmak suretiyle ihtiyaç duydukları teknolojileri transfer edebilmektedir (Grossman, and Helpman, 1991, s.43). Teknoloji transferine yönelik teşvikler ve çokuluslu şirketlere sağlanan kolaylıklar bu konuda önemli rol oynamaktadır. 
Grossman, and Helpman'ın (1991, s.45) büyümeyi ürün çeşitliliğinde artışa dayandırdığı dikey ürün geliştirme modelinde, firmalar tekelci rantlar elde etmektedir. Ar-ge faaliyetleri sonucunda rekabete konu olmayan ve dolayısıyla tüm firmalar tarafından kullanılabilen mallar üretilebilmektedir. Bilginin kamusal bir mal olduğu varsayımı altında, her bir ar-ge projesi, yeni bir ürün/tasarım geliştirmekte; tasarımcısına monopol karı şeklinde bir gelir getirmektedir. Ar-ge projeleri, mevcut bilgi sermayesi stoğuna katkı sağlamakta; sermaye stoku, gelecek nesillerin kullanabileceği fikirler ve yöntemler kümesini oluşturmaktadır.

Aghion ve Howitt (1992), bireysel yeniliklerin bütün ekonomiyi etkilediğini varsayan bir model geliştirmişlerdir. Buna göre büyüme, yenilikçi faaliyetler, eğitim ve araştırmaların üretkenliği ile pozitif; kişilerin zaman tercihi ile negatif ilişki sergilemekte; yenilikçiler arasındaki rekabet teknolojik gelişmeye yol açmaktadır. Büyüme, ar-ge ile şekillenen kalite artırıcı bir sürece dayandırılmıştır (Aghion, and Howitt, 1998, s.53; Bucci, 2005, s.6). Firmalar, patentler aracılığıyla elde ettikleri yenilikçi tekel karları beklentisi ile ar-ge yapmakta; ancak bu rantlar, zamanla kaybolmaktadır. Araştırmacı istihdamı ile yenilikler arasındaki pozitif ilişkinin ele alındığ 1 modelde, rekabetçi denge ve artan getiriler bir araya getirilerek büyümenin sürekliliği açıklanmıştır. İnovasyonların, yaratıcı yıkım etkileri ve araştırma sektöründeki yayılmalar dikkate alınmıştır.

Teknolojik gelişme, keşiflerden kar elde etmeyi amaçlayan girişimcilerin ar-ge faaliyetleri sonucu meydana gelmektedir. Yeni bir malın ortaya çıkması ve mevcutların düşük maliyet ve/veya yüksek kalite ile üretimine olanak tanıyan her türlü bilgi, beceri ve süreci içeren teknoloji, bir şeyin nasıl üretildiği, tüketildiği veya kullanıldığına ilişkin sistematik bilgiler demetidir (Bayraktutan ve Bıdırdı, 2016, s.4). Diğer üretim girdilerinden farklı olarak rekabetçi olmayan yeni bilgi, artan getirilerin kaynağı olarak görülmektedir. İçsel büyüme modelleri, ar-ge yatırımlarının yeni ürün ve/veya hizmetler oluşturduğu ya da mevcutların kalitesini iyileştirdiği argümanı doğrultusunda sermayenin marjinal verimliliğinin azalmadığı ve ülkeler arasında yakınsamanın gerçekleşmeyebileceğini öne sürmüşlerdir.

Ar-ge faaliyetleri, temelde özel sektör, kamu kesimi, üniversiteler ve ar-ge merkezlerince yürütülmektedir. Kamu ve üniversitelerce yürütülen 
çalışmalar, bilimsel bilgi birikimi üzerinde doğrudan etkiye sahiptir ve temel bilgi stoğuna katkıda bulunmaktadır (Guellec, and Potterie, 2001, s.105). Bilgi, doğrudan yabancı yatırım, lisans, teknik destek, teknoloji ithalatı, kopyalama ve tersine mühendislik gibi yollarla transfer edilebilmektedir (Dahlman, 2007: 32). İthal edilen bilgilerin verimliliğe etkisi, bu bilginin etkin kullanımı, bir diğer deyişle massetme kapasitesi ile ilgilidir. Teknoloji, ithal edildiği ülke koşullarına uygun hale gelebilmek için adaptasyona tabi olmakta; bu aşamada araştırma ve tecrübeler önem kazanmaktadır. Ar-ge, mevcut kaynakların görece etkin kullanımına olanak sağlayarak "doğrudan", bilgi ve yetenek birikimleri ile ağ ilişkilerinin oluşumuna yol açarak "dolaylı" şekilde büyümeye etki etmektedir (Griffith, 2000, s.6; OECD, 2004, s.30). Ar-ge, nihai ve ara malların ortalama maliyetini azaltmakta ve kalite ya da çeşitlilikte artışa sebep olmakta; yenilikçi girişimciler ise, verimlilik, ürün kalitesi ve pazar payını artırmak ve piyasada monopol gücü elde etmek amaciyla ar-ge harcamalarına fon ayırmaktadır. Ar-ge'nin büyüme etkileri, bilginin üretilmesi, ticarileşmesi ve yayılımını belirleyen yüksek eğitimin kalitesi, özel sektörün ar-ge etkinliği, işgücü piyasası, girişimcilik eğilimi, dışa açıklık, yabancı doğrudan yatırımlar, sermayeye erişim, kurumsal yapı, fiziki altyapının uygunluğu, kamu kesiminin ar-ge desteklemeleri vb. ülkelerin spesifik karakterlerine bağlıdır.

\section{OECD Ülkelerinde Ar-Ge}

Ar-ge harcamaları, inovatif karakteri temsilen literatürde sıklıkla kullanılmakta; ülkeler arası kıyaslamalara olanak tanıyan bir ölçü birimi olarak ise, ar-ge harcamalarının GSYİH'ya oranını ifade eden ar-ge yoğunluğu dikkate alınmaktadır. (UNESCO, 2010, s.12). Burada, OECD ülkeleri ar-ge faaliyetleri, kaynaklar ve çıktılar açısından incelenmektedir.

Büyüme ve ar-ge ilişkisini OECD örneklemi için yansıtan Grafik-1'de, 1996-2009 döneminde GSYİH'dan ar-ge harcamalarına ayrılan payın, genel itibariyle arttığı görülmektedir. Ar-ge harcamalarının ticarileşmesi zaman gerektirdiğinden büyümeyi gecikmeli olarak desteklemekte ve kriz koşullarında ar-ge ile büyüme etkileşimi zayıflamaktadır. Teorik beklentiler ve ampirik bulgular, bu durumu izaha uygun saptamalar içermektedir. 


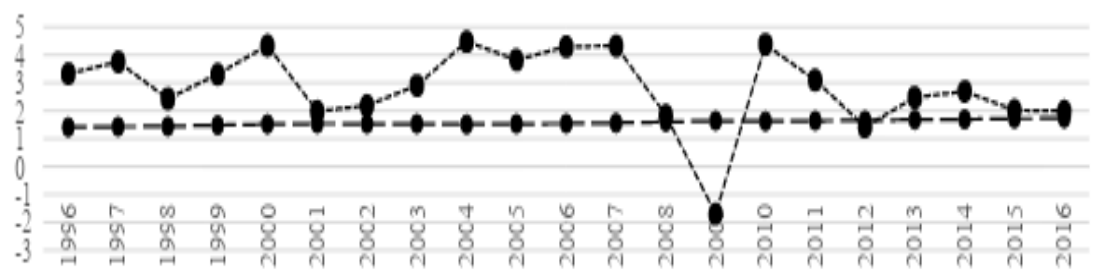

- Ar-ge Harcamalan GSYiH -KBGSYiH Büyume Oram (Ylllk, \%)

Grafik 1. OECD Ülkelerinde Ar-Ge ve KBGSYİH (1996-2016)

Kaynak: Worldbank, 2019.

Ar-ge'nin gelir grupları baz alınarak değerlendirildiği Tablo-1'e göre, GSYİH'den ar-ge harcamalarına görece büyük pay ayıran yüksek gelirli ülkelerin, global ölçekli ar-ge harcamaları ve küresel GSYİH içindeki ağırlığı, düşük gelirli ülkelere göre daha belirgindir.

Tablo 1. Gelir Gruplarna Göre Ar-Ge Harcamalarn (2007-2016)

\begin{tabular}{|c|c|c|c|c|c|c|c|c|c|c|c|c|c|c|c|}
\hline \multirow[b]{2}{*}{$\begin{array}{l}\text { Ülke } \\
\text { Gruplart }\end{array}$} & \multicolumn{5}{|c|}{$\begin{array}{c}\text { Dünya Brüt Ar-Ge Harcamala- } \\
\text { indaki Pay (\%) }\end{array}$} & \multicolumn{5}{|c|}{ Dünya GSYİH'daki Payı (\%) } & \multicolumn{5}{|c|}{$\begin{array}{l}\text { Ar-Ge Harcamalarınin } \\
\text { GSYİH'daki payı }(\%)\end{array}$} \\
\hline & $\stackrel{\text { N }}{\mathrm{S}}$ & న్ & $\stackrel{N}{\stackrel{\Xi}{*}}$ & $\underset{\omega}{\stackrel{\omega}{\omega}}$ & $\stackrel{\text { ล }}{\Omega}$ & $\stackrel{\text { s }}{5}$ & 跑 & $\stackrel{N}{\stackrel{\Xi}{*}}$ & $\underset{\omega}{\tilde{\omega}}$ & $\underset{\mathscr{\sigma}}{\sigma}$ & ָั & న్ & $\stackrel{N}{\stackrel{\Xi}{*}}$ & $\underset{\omega}{\tilde{\omega}}$ & స్ః \\
\hline Dünya & - & - & - & - & - & - & - & - & - & - & 1,57 & 1,65 & 1,65 & 1,7 & 1,68 \\
\hline OECD & 76 & 73 & 69,1 & 66 & 65,8 & 53,4 & 50,3 & 48,2 & 46,4 & 45,3 & 3,23 & 2,36 & 2,37 & 2,42 & 2,34 \\
\hline Yüksek & 79,7 & 75,6 & 72,6 & 69,3 & 65,2 & 57,7 & 54,8 & 52,8 & 51 & 51,2 & 2,16 & 2,28 & 1,65 & 1,7 & 2,33 \\
\hline $\begin{array}{l}\text { Gelirli } \\
\text { Üst-Orta } \\
\text { Gelirli }\end{array}$ & 16,1 & 19,9 & 22,7 & 25,8 & 30,5 & 27,6 & 29,5 & 30,9 & 32,1 & 31,1 & 0,91 & 1,11 & 1,21 & 1,37 & 1,12 \\
\hline $\begin{array}{l}\text { Alt-Orta } \\
\text { Gelirli }\end{array}$ & 4,1 & 4,3 & 4,5 & 4,6 & 4,09 & 13,2 & 14,2 & 14,7 & 15,2 & 14,9 & 0,48 & 0,5 & 0,5 & 0,51 & 0,42 \\
\hline $\begin{array}{l}\text { Düşük } \\
\text { Gelirli }\end{array}$ & 0,2 & 0,2 & 0,2 & 0,3 & 0,21 & 1,4 & 1,5 & 1,6 & 1,7 & 0,8 & 0,19 & 0,22 & 0,25 & 0,27 & 0,33 \\
\hline
\end{tabular}

Kaynak: UNESCO, 2016, s.26; UNESCO, 2019.

Ar-ge yoğunluğunu, 2007-2016 dönemi boyunca arttıran ve çoğunluğu yüksek gelirli olan OECD ülkelerinin, dünya ar-ge faaliyetlerinin yaklaşık üçte ikisini gerçekleştirdiği görülmektedir. Buna karşın, 2007 yılından 2016'ya üç gösterge bakımından da OECD üyeleri düşüş trendine girer- 
ken üst-orta, alt-orta ve düşük gelirli ülkelerin ilerleme kaydettikleri gözlenmektedir. Üst-orta gelirli ülkeler, söz konusu dönemde GSYİH'den arge'ye ayırdıkları payı \% 23,07; küresel GSYİH'daki paylarını ise, \% 12,68 oranında yükseltmişlerdir. Bu sonuçlar, ar-ge ve büyüme ilişkisi bağlaminda beklentilerle örtüşmektedir.

1990'lardan itibaren kamu ve yükseköğrenim ar-ge harcamaları arasinda bir değiş tokuş yaşanmaktadır (OECD, 2018). Bu durum, kamunun, düzenleyici aktör olarak araştırma kurumları tesis etmesi, ar-ge destekleriyle özel kesim ve üniversitelerin ar-ge faaliyetlerini teşvik yoluna gitmesi ve araştırma çıktılarının ticarileştirilmesi rolünü özel kesime yüklemesi ile izah edilmektedir. Yatırımların piyasa odaklı planlanması neticesinde özel sektör daha fazla ar-ge faaliyeti yürütmüş; patentleme eğilimi ve inovasyon faaliyetleri hız kazanmıştır. Bilgi ve iletişim teknolojilerine yapılan yatırımlar, yeni iş stratejileri, süreçler ve organizasyonel yapılar ile bütünleşmiş; OECD ülkelerinde emek üretkenliğinde meydana gelen artışlar yoluyla büyümeye katkı sağlamıştır.

Finansman kaynağına göre ar-ge yoğunluğu, ülkeler arasında farkl1laşmaktadır. 2011-2016 döneminde OECD ar-ge harcamalarının GSYİH'ya oranı, özel kesim için ortalama \% 1,61 iken kamu kesiminde \% 0,26; yükseköğrenimde \% 0,42 olmuştur. 1990'lı yılların ortasında özel kesim ar-ge harcamaları GSYİH'nın \% 1,32'si iken 2017'de \% 1,67'sine yükselmiştir (UNESCO, 2016, s.27; UNESCO, 2019). Kamu kesimi ar-ge harcamalarının yoğunluğu, ele alınan dönemde genel olarak artarken, özellikle 2005 ve 2006 yıllarında özel kesim ar-ge harcamalarında görülen azalma, kamu arge fonları ile dengelenmiştir. Özel kesimin ar-ge faaliyetlerine aktif katılımı ve görece büyük oranda harcama yapması, rekabet güdüsüne dayandırılabilir. Buna göre, katma değeri yüksek ürünler üretme ve pazar payını arttırma çabası, özel sektörü ar-ge yapmaya yöneltmektedir. Yükseköğrenim ar-ge harcama yoğunluğunda, ele alınan dönemde meydana gelen yaklaşık \% 20,4 oranındaki yükselişin yeni üniversite ve bölümlerin açılmasından ileri geldiği düşünülmektedir. Kamu kesimi ar-ge harcamalarının GSYİH'ya oranında meydana gelen \% 2 civarındaki azalma ise, temel araştırmaların çoğunlukla üniversiteler; uygulamalı araştırma ve geliştirmelerin ise, özel sektör tarafından yürütülmesinden kaynaklanmaktadir. 


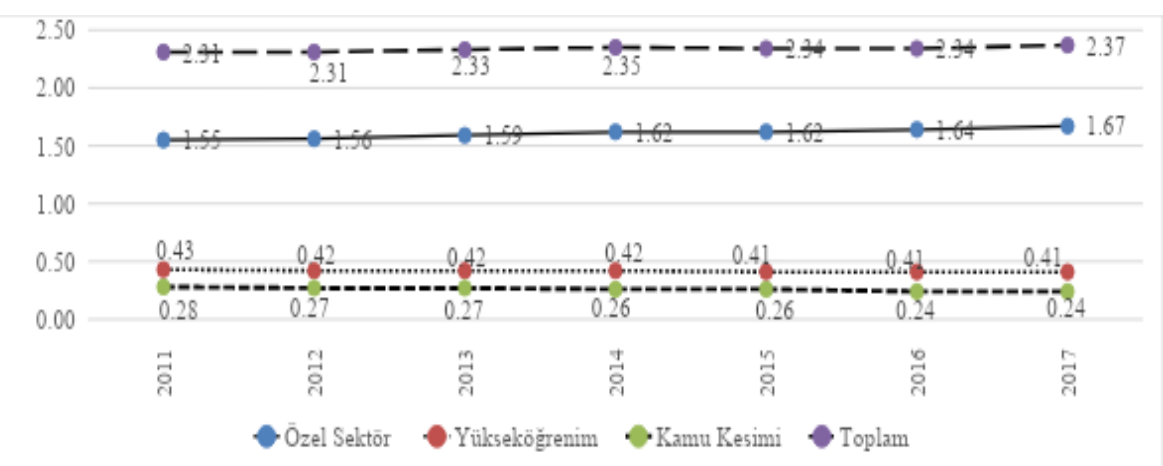

Grafik 2. OECD Ülkelerinde Kaynağına Göre Ar-Ge Yoğunluğu (2011-2017, \%) Kaynak: OECD, 2019.

Üniversiteler ve kamu araştırma kurumları, özel sektör araştırmalarının tamamlayıcısı olarak uzun vadeli ve yüksek riskli çalışmaları üstlenmektedir (OECD, 2010a, s. 168). 2011-2017 döneminde brüt ar-ge harcamaları genel olarak yükseliş trendi sergilemiş; kamu kesimi ar-ge yoğunluğu gerilerken yükseköğrenim ve özel kesim ar-ge yoğunluğu artmıştır. OECD ülkelerinde özel kesim ar-ge harcamaları, 2011 yılında GSYİH'nın \% 0,43'ü iken, 2017 yılında bu oran \% 1,67'dir. Özel sektör payında gözlenen artış, artan uluslararası ticaret hacmi ve rekabet edebilirlik olgusu ile açıklanabilir. Yükseköğrenim ar-ge harcamalarının GSYİH'daki payı, ele alınan dönemde anlamlı şekilde değişmezken kamu kesimi ar-ge harcamalarının GSYİH'daki payı ise, ortalama olarak $\% 0,28$ 'den $\% 0,24$ 'e gerilemiştir.

İnovasyon çıtı düzeyi, üniversite ve araştırma merkezleri gibi birimlerin çalışma koşullarına ilişkin standart ve düzenlemelere bağlıdır. Bu birimler arasındaki etkileşimin kalitesi ve yoğunluğu, inovasyon çıktılarının belirleyicilerindendir (OECD, 2011, s. 38). OECD genelinde 2011 yllında yüksek eğitim alanında yapılan ar-ge harcamaları, toplam brüt ar-ge harcamalarının \% 17'sine yakındır (OECD, 2013, s.100). OECD ortalamasına göre 2001 yılında özel sektör tarafından yürütülen ar-ge faaliyetlerinin \% 7'si hükümet tarafından fonlanırken, 2011 yılında bu oran \% 9'a ulaşmıştır. OECD ülkelerinde özel kesim tarafından yapılan ar-ge harcamaları düzeyi, 2011 yılında GSYİH'nın \% 1,55'i iken, 2017 yılında bu oran \% 1,67'dir. 
Kamu araştırma kurumları, piyasanın gerek duyduğu teknik gereklilikleri yorumlayarak üniversiteler ve firmalar arasında bir aracı rolü de üstlenmektedir (OECD, 2011b, s.133). Temel fonksiyonu öğretim ve araştırma olan üniversiteler ile kamu araştırma kurumları, özel sektör araştırmalarının tamamlayıcısıdır (OECD, 2010b, s.168). OECD ortalamasında toplam ar-ge faaliyetlerinin \% 11,1'ini kamu kesimi gerçekleştirirken, temel araştırma çıtılarının \% 75'inin üniversite ve kamu kurumları ortaklığında üretildiği görülmektedir (OECD, 2014b, s.195). Kamu araştırmaları, temel araştırmaların yanısıra savunma, sağlık ve enerji gibi ulusal ihtiyaçları da karşılamaktadır.

\section{İlgili Literatür}

Ar-ge ve büyüme arasındaki etkileşimi araştıran çok sayıda yayın yapılmıştır. Aşağıda, bu çalışmanın perspektifi ışığında seçilen örnekler özetlenecektir.

Frank R. Lichtenberg (1993), büyüme ile özel ve kamu kesimi ar-ge harcamaları arasındaki ilişkiyi 98 ülke ve 1964-1989 dönemi için incelemiş; özel ar-ge harcamalarının sosyal getiri oranının, fiziki yatırımlarınkinden yedi kat fazla olduğunu saptamıştır. GSYİH'nın özel kesimce fonlanan arge sermaye stoğuna göre elastikiyeti, fiziki sermaye elastikiyetinden yaklaşık 1/3 oranında büyüktür. Analiz sonuçlarına göre, özel sektör ar-ge harcamaları ile büyüme arasında bir etkileşim bulunurken, kamu sektörünce yapılan harcamaların büyüme üzerinde etkisinin olmadığı ya da negatif etki doğurduğu gözlenmiştir.

Rajeey K. Goel ve James E. Ram (1994), 1960-1985 dönemi için 18 GÜ ve 36 GOÜ'den oluşan 54 ülkede, büyüme ile ar-ge harcamaları arasındaki ilişkiyi çoklu regresyon analizi ile test etmiştir. Sermaye, işgücü ve ar-ge harcamalarının reel üretim üzerindeki etkilerinin araştırıldığı çalışmada, ar-ge harcamalarının elastikiyeti istatistiksel olarak anlamlı ve pozitif bulunmuştur. Her iki ülke grubu için okullaşma oranı değişkeni analize dahil edildiğinde, ar-ge katsayısının büyüklüğü, GOÜ için $0.17^{\prime}$ den 0.477 'ye; GÜ için ise, 0.185 'den 0.235 'e yükselmiştir. Sadece yüksek gelirli ülkelerde ar-ge harcamaları ile büyümenin ilişkili olduğu ortaya konmuş; ancak ar- 
ge harcamalarından ekonomik büyümeye doğru ya da ekonomik büyümeden ar-ge harcamalarına doğru bir nedensellik olup olmadığı belirtilmemiştir.

Walter G. Park (1995), 10 OECD ülkesinin 1970-1987 dönemi için kamu ve özel sektör ar-ge yatırımlarının ekonomik büyüme üzerindeki etkisini panel veri analizi ile incelemiştir. Çalışmanın bulgularına göre, yerel özel sektör ar-ge yatırımları, hem yerel hem de yabancı faktör verimliliğindeki artış için kamu sektörü ar-ge yatırımlardan daha önemli bir belirleyici etkendir. Ayrıca yabancı ar-ge yatırımlarının özel sektör yatırımlarını canlandırması vasıtasıyla, verimlilikteki artış üzerinde dolaylı bir etkisi söz konusudur.

Andrea Bassanini ve Stefano Scarpetta (2001), büyüme, yatırım, finansal yapı, makroekonomik koşullar, beşeri sermaye ve ar-ge harcamaları arasındaki ilişkiyi, 21 OECD ülkesi ve 1971-1998 dönemi için panel veri analizi ile test etmiştir. Modelde, kişi başına GSYİH artış oranı bağımlı değişken iken kişi başına GSYİH artışının bir dönem gecikmeli değeri, özel sabit sermaye oluşumunun reel GSYIHH'ya oran1, 25-64 yaş grubunda ortalama okullaşma yılı ve 15-64 yaş nüfus artış oranı bağımsız değişkenlerdir. Bulgulara göre, ar-ge harcamalarındaki \% 1'lik yükselme, büyümeyi \%0,3-0,4 arasında arttırmaktadır. Özel kesim ar-ge faaliyetlerinin sosyal getiri oranı, kamu kesimine oranla yüksek bulunmuştur. Kamu kesimince yürütülen faaliyetlerin çıktıyı negatif etkilediği gözlenmiş ve buna dayalı olarak, kamu kesiminin özel kesimi dışlayıp düşük ar-ge etkinliğine yol açtığı ileri sürülmüştür.

Dominique Guellec ve Bruno Van Pottelsberghe De La Potterie (2001), verimlilik artışı ve teknolojik değişme arasındaki uzun dönemli ilişkiyi, teknolojik gelişmeyi temsilen yerli özel, kamu ve yabancı kaynaklı özel arge stoğu değişkenlerini kullanarak, 1980-1998 dönemi ve 16 OECD ülkesi için panel veri yöntemiyle analiz etmiştir. Teknolojinin verimlilik artışına katkısı, yabancı ve yerli teknolojiler arasındaki farklar, kamu ve üniversitelerin gerçekleştirdikleri ar-ge'nin verimlilik üzerindeki etkisi ve ülkelerin spesifik özelliklerinin yeni teknoloji kaynaklarını etkileme biçimlerini araştıran bu çalışmada, ticaret ortağı ülkelerdeki ar-ge stokunun uluslararası yayılmalar yoluyla büyümeye katkıda bulunduğu tespit edilmiştir. Kamu ar-ge stoğunun verimlilik elastikiyeti, üniversiteler ve özel kesim ar-ge yoğunluğunun fazla olduğu ülkelerde daha yüksek bulunmuştur. 
Martin Falk (2007), 1970-2004 dönemi ve OECD ülkeleri için panel veri regresyon analizi yaparak ar-ge yatırımlarının büyüme üzerindeki etkilerini tespit etmeye çalışmıştır. Bağımlı değişken, kişi başına GSYİH büyüme oranı; bağımsız değişkenler ise, 25-64 yaş grubu nüfusun ortalama okullaşma yılı, yatırım oranı ve yüksek teknoloji sektörlerinde özel kesim ar-ge harcamalarının payıdır. Tahmin sonuçlarına göre, özel kesim ar-ge harcamalarının GSYİH'daki payına ilişkin katsayı pozitif çıkmış; yüksek teknolojili sektörlerin özel ar-ge harcamalarının büyüme üzerinde yayılmalar yoluyla ilave pozitif bir etki doğurduğu saptanmıştır. Kişi başına GSYİH'nın yatırım oranına göre elastikiyeti kısa ve uzun dönem için sırasıyla 0,15 ve 1,4; özel kesim ar-ge harcamalarına göre elastikiyeti ise, 0,024 ve 0,22 olarak tespit edilmiştir. Diğer taraftan, özel kesim ar-ge harcamalarındaki \% 10'luk artış, kişi başına GSYİH'yı kısa dönemde \%0,26; uzun dönemde ise, $\% 2,3$ oranında ve pozitif yönde etkilemektedir.

Mosahid Khan et. al. (2010), 16 OECD ülkesi arasında görülen verimlilik farklılıklarının kaynağını, 1982-2004 dönemi için dinamik panel veri analizi ile test etmiş̧ir. Bulgulara göre, özel, kamu ve yabancı ar-ge faaliyetleri ve beşeri sermaye, verimlilik artışları üzerinde pozitif ve istatistiksel olarak anlamlı etkiler yapmaktadır. Bilgi-iletişim teknolojileri, altyapı, doğrudan yabancı sermaye çıkışı ve girişi, hizmetler sektörünün büyüklüğü, finansal yapının gelişmişliği, verimlilik üzerinde pozitif etkiler ortaya koymuştur. Görece büyük bilgi ve beşeri sermaye stoğuna sahip ABD ve Almanya gibi ülkelerin, İspanya ve Yeni Zelanda gibi düşük ar-ge yoğunluğuna sahip ülkelere kıyasla, yüksek verimlilik kazançları elde edeceği ileri sürülmüştür.

Alireza Poorfaraj et. al. (2011), 16 GOÜ ve 2000-2008 dönemi için ar-ge, beşeri sermaye ve teknoloji yayılmalarını kapsayan bilgi ekonomisi endeksi, işgücü, gayrisafi sabit sermaye oluşumu, mal ve hizmet ihracatı, kamu eğitim harcamaları ile GSYİH arasındaki ilişkiyi panel veri yöntemi ile analiz etmişlerdir. Tahmin sonuçlarına göre, eğitim harcamaları dışındaki bütün bağımsız değişkenler, GSYİH'yı pozitif ve anlamlı şekilde etkilemektedir.

Luisa Blanco et. al. (2013), özel kesim ar-ge faaliyetleri ile toplam faktör verimliliği ilişkisini ABD ve 1963-2007 dönemi için panel kointegrasyon testiyle araştırmış; uzun dönemde ar-ge'nin çıtı üzerindeki etkileri pozitif, ölçülebilir ve anlamlı bulunmuştur. Ar-ge harcamalarındaki \%1'lik 
yükselme, 1963 yılında TFV üzerinde \%0,056'llk bir artışa yol açarken bu oran 2007 yılında \% 1,143'e ulaşmıştır.

Tarek Sadraoui et. al. (2014), inovasyon ve ar-ge işbirlikleri arasındaki ilişkiyi 32 ülke ve 1970-2012 dönemi verileriyle analiz etmiştir. Kişi başına GSYİH bağımlı; sermaye, işgücü, ar-ge harcamalarının GSYİH'ya oranı, uluslararası ortaklıklar yoluyla yürütülen ar-ge faaliyetleri kapsamında yapılan harcamalar ise, bağımsız değişkenler olarak ele alınmış; büyümenin ar-ge işbirliklerini arttırdığı yönünde güçlü bir nedensellik ortaya konmuştur. Yurtiçi ar-ge yoğunluğundaki artışın, ülkeler arasındaki ar-ge işbirliklerini hızlandırdığı ve böylelikle yeni ürün üretimi ya da mevcutların kalite artışına yol açan teknolojik gelişmenin hız kazandığı ileri sürülmüsstür. Teknolojik gelişmenin önemli bir belirleyicisi olarak görülen ar-ge işbirlikleri yoluyla oluşturulan ağlarda bilgi akışının artacağı ve dışsallıklar yoluyla büyümenin gerçekleşeceği düşünülmüştür.

Analitik çalışmaların çoğunda (Bayraktutan ve Kethudaoğlu, 2017; Falk, 2007; Bassanini, et. al., 2001; OECD, 2003; Khan, Luintel, and Theodoridis, 2010), ar-ge harcamaları, verimlilik, çıktı ve büyüme ile ilişkilendirilmiş; ülkeler arasındaki üretim ve verimlilik farklarının kaynağı olarak değerlendirilmiştir.

\section{Model, Değişkenler ve Veri Seti}

Ar-ge ve iktisadi büyüme arasındaki ilişkiyi belirlemeyi amaçlayan bu çalışmada, "eğim katsayısının sabit olduğu fakat sabit terimin kesit ve zaman boyunca farklılık gösterdiği" varsayımına dayalı Çift Yönlü Sabit Etkiler Modeli (Hausman Spesifikasyon ve F anlamlılık testi sonuçlarına göre) ve standart üretim faktörleri yanında, genel bir ifadeyle bilgi sermayesi olarak nitelenebilen değişkenler arasında yer alan ar-ge harcamalarını dikkate alan toplam üretim fonksiyonu kullanılmıştır. Bu doğrultuda ele alınan modeller, Bassanini ve Scarpetta (2001), Ülkü (2004) ile Goel, Payne ve Ram (2008) esas alınarak geliştirilmiş; özel kesim ar-ge harcamalarının büyüme üzerindeki etkisini belirlemek için Eşitlik-1; kamu kesimi için Eşitlik-2; yükseköğrenim ve büyüme etkileşimi için Eşitlik-3 oluşturulmuştur: 
- $\quad$ Model 1: KBBit $=\beta_{1 \mathrm{t}}+\beta_{2} \mathrm{D}(\mathrm{BERD}) \mathrm{it}+\beta_{3}$ SERMAYEit $+\beta_{4}$ POPGit $+\beta_{5}$ TICARETit $+\beta_{6}$ ENFit $+\beta_{7}$ D (EGITIM)it $+\varepsilon$ it

- $\quad$ Model 2: KBBit $=\beta_{1+}+\beta_{2} \mathrm{D}($ GOVERD $)$ it $+\beta_{3}$ SERMAYEit $+\beta_{4}$ POPGit $+\beta_{5}$ TICARETit $+\beta_{6}$ ENFit $+\beta$ D (EGITIM)it $+\varepsilon$ it

- $\quad$ Model 3: KBBit $=\beta_{1 t}+\beta_{2} \mathrm{D}($ HERD $)$ it $+\beta_{3}$ SERMAYEit $+\beta_{4}$ POPGit $+\beta_{5}$ TICARETit $+\beta_{6}$ ENFit $+\beta_{7} \mathrm{D}($ EGITIM $)$ it $+\varepsilon$ it

BERD, özel kesim ar-ge yoğunluğunu; GOVERD, kamu kesimi ar-ge yoğunluğunu; HERD, yükseköğrenim ar-ge yoğunluğunu; SERMAYE, gayri safi sabit sermaye oluşumunun GSYİH içindeki payını; POPG, 15-64 yaş nüfusun yıllık artış oranını; EGITIM, yükseköğrenim mezunlarının sayısını; RESPERS, ar-ge alanında istihdam edilen tam zaman eşdeğeri araştırmacı personel sayısını; TICARET, dışa açıklık oranını (İhracat+İthalat/GSYİH); ENF, özel nihai tüketim harcamaları deflatörünün yıllık artış oranını; bağımlı değişken KBB ise, kişi başına GSYİH'daki yıllık büyüme oranın ifade etmektedir. Modelde yer alan $\mathrm{i}=1,2, \ldots . ., 29$ ülkeleri, t zamanı, $\beta 1$ t sabit katsayısını ve $\varepsilon$ hata terimini göstermektedir. Analiz için OECD üyesi 29 ülkenin 1996-2015 dönemine ait yıllık verileri kullanılmıştır. Avusturalya, Şili, İsrail, Yeni Zelanda, İsviçre ve Luxemburg, veri setlerinde büyük kayıplar bulunması sebebiyle analiz dışı bırakılmış; analize tabi tutulan ülkelerde gözlenen görece küçük veri boşlukları, Neville tekniği kullanılarak interpolasyona tabi tutulmuştur. Değişkenler, daha önceden yapılan ampirik çalışmalar ve verilerin ulaşılabilirliği dikkate alınarak seçilmiştir. BERD, GOVERD, HERD ve RESPERS, OECD Temel Bilim ve Teknoloji Göstergeleri; EGITIM, UNESCO; diğer değişkenler ise, Dünya Bankası veritabanından elde edilmiştir. Modellerin tahmininde, Eviews 9.0 ve Stata 10 paket programlarından yararlanılmıştır.

\section{Analiz ve Bulgular}

LLC ve IPS durağanlık testi sonuçları Tablo-2' de verilmiştir. Analizlerde sabitli ve sabitli-trendli olmak üzere iki model kullanılmış; gecikme değerleri, Schwartz Bilgi Kriteri'ne (SIC) göre otomatik olarak belirlenmiştir. 
Tablo 2. Birim Kök Testi Sonuçları

\begin{tabular}{|c|c|c|c|c|c|c|c|c|}
\hline \multirow{4}{*}{$\begin{array}{l}\text { Değiş- } \\
\text { kenler }\end{array}$} & \multicolumn{8}{|l|}{ Seviyeler } \\
\hline & \multicolumn{4}{|c|}{$\begin{array}{l}\text { Levin, Lin ve } \\
\text { Chu }\end{array}$} & \multicolumn{4}{|c|}{ Im, Pesaran, and Shin } \\
\hline & \multicolumn{2}{|c|}{ Sabitli } & \multicolumn{2}{|c|}{ Sabitli/Trendli } & \multicolumn{2}{|l|}{ Sabitli } & \multicolumn{2}{|c|}{ Sabitli/Trendli } \\
\hline & t-stats & Prob & t-stats & Prob & t-stats & Prob & t-stats & Prob \\
\hline & - & & & & & & & \\
\hline \multirow[t]{2}{*}{ KBB } & 11,0464 & 0,00000 & $-9,71685$ & 0,00000 & $-9,04613$ & 0,00000 & $-6,92363$ & 0,00000 \\
\hline & - & & & & & & & \\
\hline \multirow[t]{2}{*}{ BERD } & 4,59424 & 0,00000 & $-1,51430$ & 0.0650 & 0.51547 & 0.6969 & $-1,36073$ & 0.0868 \\
\hline & - & & & & & & & \\
\hline HERD & 7,29912 & 0,00000 & 0,86004 & 0,80510 & $-0,32347$ & 0,37320 & 0,09822 & 0,53910 \\
\hline GO- & - & & & & & & & \\
\hline VERD & 2,53256 & 0,00570 & $-1,27860$ & 0,10050 & 2,25806 & 0,98800 & 0,21979 & 0,58700 \\
\hline SER- & - & & & & & & & \\
\hline MAYE & 3,09790 & 0,00100 & $-2,45462$ & 0,00710 & $-3,35436$ & 0,00040 & $-2,41116$ & 0,00800 \\
\hline & - & & & & & & & \\
\hline \multirow[t]{2}{*}{ ENF } & 10,9803 & 0,00000 & $-9,75974$ & 0,00000 & $-8,88958$ & 0,00000 & $-7,67564$ & 0,00000 \\
\hline & - & & & & & & & \\
\hline POPG & 0,54071 & 0,09440 & $-1,04753$ & 0,04740 & $-2,97574$ & 0,00150 & $-5,32396$ & 0,00000 \\
\hline TICA- & - & & & & & & & \\
\hline RET & 3,20272 & 0,00070 & $-5,56333$ & 0,00000 & 1,20712 & 0,88630 & $-4,18388$ & 0,00000 \\
\hline EGITIM & 1,49873 & 0,93300 & $-1,49657$ & 0,06730 & 5,08787 & 1,00000 & $-0,80619$ & 0,21010 \\
\hline \multirow{4}{*}{$\begin{array}{l}\text { Değiş- } \\
\text { kenler }\end{array}$} & \multicolumn{8}{|l|}{ Farklar } \\
\hline & \multicolumn{4}{|c|}{ Levin, Lin ve Chu } & \multicolumn{4}{|c|}{ Im, Pesaran, and Shin } \\
\hline & \multicolumn{2}{|c|}{ Sabitli } & \multicolumn{2}{|c|}{ Sabitli/Trendli } & \multicolumn{2}{|l|}{ Sabitli } & \multicolumn{2}{|c|}{ Sabitli/Trendli } \\
\hline & t-stats & Prob & t-stats & Prob & t-stats & Prob & t-stats & Prob \\
\hline KBB & $-21,763$ & 0,00000 & $-18,271$ & 0,00000 & $-19,4142$ & 0,00000 & $-15,3316$ & 0,00000 \\
\hline BERD & $-13,329$ & 0,00000 & $-12,177$ & 0,00000 & $-12,7722$ & 0,00000 & $-12,0130$ & 0,00000 \\
\hline HERD & $-10,092$ & 0,00000 & $-9,1685$ & 0,00000 & $-11,7511$ & 0,00000 & $-10,3047$ & 0,00000 \\
\hline \multicolumn{9}{|l|}{ GO- } \\
\hline VERD & $-15,363$ & 0,00000 & $-11,279$ & 0,00000 & $-15,2310$ & 0,00000 & $-11,2669$ & 0,00000 \\
\hline \multicolumn{9}{|l|}{ SER- } \\
\hline ENF & $-21,575$ & 0,00000 & $-17,204$ & 0,00000 & $-19,9707$ & 0,00000 & $-15,4590$ & 0,00000 \\
\hline POPG & $-9,7655$ & 0,00000 & $-8,9291$ & 0,00000 & $-12,7211$ & 0,00000 & $-9,71612$ & 0,00000 \\
\hline \multicolumn{9}{|l|}{ TICA- } \\
\hline EGITIM & $-8,6558$ & 0,00000 & $-7,8057$ & 0,00000 & $-9,64716$ & 0,00000 & $-9,25560$ & 0,00000 \\
\hline
\end{tabular}

Ampirik sonuçlara göre, KBB, SERMAYE, ENF, POPG, TICARET değişkenleri için her iki modelde "birim kök vardır" şeklindeki Ho hipotezi reddedilmekte; serilerin düzeyde durağan olduğu anlaşılmaktadır. Tablo2' deki BERD, GOVERD, HERD ve EGITIM için yapılan IPS (2003) ve LLC (2002) düzey birim kök testi sonuçlarına göre, \% 5 anlamlılık düzeyinde 
$\mathrm{H}_{0}$ hipotezi kabul edildiğinden serilerin durağan olmadıkları tespit edilmiştir. Fark serileri ile oluşturulacak modellerde sahte regresyon sorunu ortadan kalkacağından, BERD, GOVERD, HERD ve EGITIM serileri, birincil farkları alınarak regresyon analizine dahil edilmişlerdir.

Değişkenlerin durağanlığı belirlendikten sonra hata terimlerinin gecikmeli değerleriyle ilişkili olup olmadığını tespit etmek amacıyla Wooldridge otokorelasyon testi yapılmış; hesaplanan $\mathrm{F}$ değeri, \% 10 anlamlılık düzeyindeki tablo değerinden büyük olduğundan, Ho hipotezi olan "birinci dereceden otokorelasyon yoktur" boş hipotezi reddedilerek otokorelasyon bulunduğuna karar verilmiştir. Otokorelasyonun varlı̆̆ı, serilerde yapılan Period Weights PCSE düzeltmesi ile giderilmiştir.

Panel veri çalışmalarında, Hausman testi (1978) ile sabit ve rassal etki modellerinin parametre tahmincileri arasında sistematik farklılığın olup olmadığı incelenebilmektedir. Hausman test istatistiği, "tesadüfi etkiler tahmincisi doğrudur" sıfır hipotezi altında k serbestlik dereceli ki-kare dağllımını göstermektedir. Hausman testi sonucunda alternatif hipotez $\left(\mathrm{H}_{1}\right.$ : $\left.\operatorname{cov}\left(\mu_{i}, X_{i}\right) \# 0\right)$ kabul edilirse, tesadüfi etkiler modelinin tahmincisi tutarsız; sabit etkiler tahmincisi ise, tutarlı ve etkindir. Bu nedenle, modelde çift yönlü sabit etkiler tahmincisi kullanılmaktadır. Sıfır hipotezi $\left(\mathrm{H}_{0}\right.$ : $\left.\operatorname{cov}\left(\mu_{\mathrm{i}}, \mathrm{X}_{\mathrm{i}}\right)=0\right)$ kabul edilirse, tesadüfi etkiler modelinin tahmincisi tutarlı, etkin ve yansız; sabit etkiler tahmincisi ise, tutarlı ancak etkin değildir. Bu durumda tesadüfi etkiler tahmincisi kullanılmaktadır (Wooldridge, 2002, s.450).

Bu çalışmada oluşturulan modeller, ortak etkiler (havuzlanmış regresyon), sabit etkiler ve rassal etkiler olmak üzere üç tahminciye göre tahmin edilmiştir. Sabit ya da rassal etkilerden hangisinin kullanılacağına karar vermek için yapılan Hausman testlerinde $t$ istatistiğine ilişkin olasılık değeri Model-1 için 0,0007; Model-2 için 0,0001; Model-3 için 0,0002 çıktığından model parametreleri arasında sistematik farklılık olmadığına ilişkin $\mathrm{H}_{0}$ hipotezi reddedilerek sabit etki modeli, rassal etki modeline tercih edilmiştir.

Regresyon analizinde kullanılacak tahmincinin belirlenmesine yönelik yapılan testlerden F anlamlılık testi sonuçları, sabit etkiler ile havuzlanmış EKK (pooled OLS) tahmincisini karşılaştırmaktadır (Hsiao, 2003). Fgrup istatistiği, sabit etkiler modelinde birimler arasında farklılı̆ı̆n olup olmadığını; Fperiyod, zaman etkisini; Ftwoway ise, grup ve zaman etkilerinin 
anlamlılığını test etmektedir. Test sonuçlarına göre, bütün modeller için birimler arasında farklılık bulunmadığı ve ortak etkinin geçerli olduğunu ifade eden boş hipotez reddedilmiş; birimler arasında farklılık bulunduğu ve sabit ya da rassal etkinin geçerli olduğunu ifade eden alternatif hipotez kabul edilmiştir. Fgroup, Ftime ve Ftwoway istatistiklerinin her biri, bütün modeller için istatistiki olarak anlamlı görüldügünden, grup ve zaman etkilerini dikkate alan çift yönlü sabit etkiler modeli aracılığıyla regresyon modelinin tahmin edilmesi gerekmektedir.

Tablo 3. F Testi Sonuçları

\begin{tabular}{llllll}
\hline \multirow{2}{*}{ Modeller } & \multirow{2}{*}{ Test } & \multicolumn{2}{c}{ Tek Yönlü Sabit Etkiler Modeli } & \multicolumn{2}{c}{ Çift Yönlü Sabit Etkiler Modeli } \\
\cline { 2 - 6 } & & İstatistik & Prob. & İstatistik & Prob. \\
\hline Model 1 & Fgroup & 2,32277 & 0,00020 & 3,808253 & 0,00000 \\
\cline { 2 - 6 } & Ftime & & 19,568750 & 0,00000 \\
\cline { 2 - 6 } & Ftwoway & & 9,987021 & 0,00000 \\
\hline \multirow{2}{*}{ Model 2 } & Fgroup & 2,47118 & 0,00010 & 3,894421 & 0,00000 \\
\cline { 2 - 6 } & Ftime & & 22,020668 & 0,00000 \\
\cline { 2 - 5 } & Ftwoway & & & 11,223979 & 0,00000 \\
\hline \multirow{2}{*}{ Model 3 } & Fgroup & 2,43093 & 3,00010 & 3,911694 & 0,00000 \\
\cline { 2 - 5 } & Ftime & & 21,674277 & 0,00000 \\
\cline { 2 - 5 } & Ftwoway & & 11,028084 & 0,00000 \\
\hline
\end{tabular}

Tablo 4. Pesaran CD Test Sonuçları

\begin{tabular}{lllll}
\hline \multirow{2}{*}{ Modeller } & \multicolumn{2}{l}{ Tek Yönlü Sabit Etkiler Modeli } & \multicolumn{2}{l}{ Çift Yönlü Sabit Etkiler Modeli } \\
\cline { 2 - 5 } & İstatistik & Prob. & İstatistik & Prob. \\
\hline Model 1 & 4029778 & 0,0000 & 0,887692 & 0,3747 \\
\hline Model 2 & 45,44396 & 0,0000 & 1,081208 & 0,2796 \\
\hline Model 3 & 43,90959 & 0,0000 & 0,494654 & 0,6208 \\
\hline
\end{tabular}

Yatay kesit bağımlılığının varlığı, panelin zaman boyutu yatay kesit boyutundan büyük olduğunda Breusch-Pagan Lagrange Multiplier (LM) (1980) testiyle; her ikisinin de büyük olduğu durumlarda, kısaca Pesaran CD olarak ifade edilen Pesaran Cross-Section Dependence (2004) testiyle araştırılabilmektedir. Bu çalışmada 29 ülke ve 20 yıl olduğu için Pesaran CD (2004) testi kullanılmıştır. Çift yönlü tahmin sonucu elde edilen ve Tablo-5'te gösterilen Pesaran CD test değerleri \%1, \%5 ve \%10 düzeylerinin her biri için istatistiksel olarak anlamlı görüldügünden, yatay kesit bağımlılığının bulunmadığına işaret eden $\mathrm{H}_{0}$ hipotezi kabul edilmiştir. 
Tablo 5. Model 1 Tahmin Sonuçları

\begin{tabular}{lllll}
\hline Değişkenler & Katsayı & Standart Hata & t istatistiği & Prob \\
\hline C & $-7,93998$ & 1,46370 & $-5,42460$ & 0,00000 \\
\hline D(BERD) & 2,61738 & 0,94320 & 2,77501 & 0,00570 \\
\hline SERMAYE & 0,33659 & 0,04812 & 6,99513 & 0,00000 \\
\hline POPG & $-1,41338$ & 0,33742 & $-4,18874$ & 0,00000 \\
\hline TICARET & 3,51735 & 1,00306 & 3,50662 & 0,00050 \\
\hline ENF & $-0,04504$ & 0,02152 & $-2,09366$ & 0,03680 \\
\hline D(EGITIM) & $-3,45753$ & 1,33864 & $-2,58287$ & 0,01010 \\
\hline & R-squared & 0,59911 & Mean dependent var & 2,02277 \\
\hline & Adjusted R-squared & 0,55725 & S.D. Dependent var & 3,44956 \\
\hline & S.E. of regression & 2,29532 & Akaike info criterion & 4,59087 \\
\hline & Sum squared resid & 2623,71200 & Schwartz criterion & 5,00561 \\
\hline & Log likelihood & $-1211,78300$ & Hannan-Quinn & 4,75293 \\
\hline & F-statistic & 14,31222 & Durbin-Watson stat & 1,18953 \\
\hline & Prob (F-statistic) & 0,00000 & & \\
\hline
\end{tabular}

Sabit varyans, doğrusal regresyon modelinin önemli varsayımlarından biridir. Hata terimi varyanslarının bağımsız değişkenlerle birlikte değişmesi durumunda değişen varyans sorunu ortaya çıkmaktadır. Doğrusal regresyon modelinin bir diğer önemli varsayımı da, hata teriminin birbirini izleyen değerleri arasında ilişki olmadığıdır. Hata terimleri arasında ilişki olması durumunda otokorelasyon sorunu ortaya çıkmaktadır (Hsiao, 2003, s.74; Baltagi, 2008, s.68).

Tablo 6. Model 2 Tahmin Sonuçları

\begin{tabular}{lllll}
\hline Değişkenler & Katsay1 & Standart Hata & t istatistiği & Prob \\
\hline C & $-7,61692$ & 1,46222 & $-5,20915$ & 0,00000 \\
\hline D(GOVERD) & 1,83633 & 0,81960 & 2,24051 & 0,02550 \\
\hline SERMAYE & 0,33566 & 0,04824 & 6,95769 & 0,00000 \\
\hline POPG & $-1,39071$ & 0,33629 & $-4,13551$ & 0,00000 \\
\hline TICARET & 3,24766 & 1,00542 & 3,23016 & 0,00130 \\
\hline ENF & $-0,04706$ & 0,02147 & $-2,19233$ & 0,02880 \\
\hline D(EGTIM) & $-2,05184$ & 1,10901 & $-1,85015$ & 0,06490 \\
\hline & R-squared & 0,59731 & Mean dependent var & 2,02277 \\
\hline & Adjusted R-squared & 0,55526 & S.D. Dependent var & 3,44956 \\
\hline & S.E. of regression & 2,30048 & Akaike info criterion & 4,59536 \\
\hline & Sum squared resid & 2635,52300 & Schwartz criterion & 5,01010 \\
\hline & Log likelihood & $-1213,02100$ & Hannan-Quinn & 4,75742 \\
\hline & F-statistic & 14,20517 & Durbin-Watson stat & 1,18525 \\
\hline & Prob (F-statistic) & 0,00000 & & \\
\hline
\end{tabular}


Modelde kullanılan ülke sayısı çok fazla olduğunda kesitler arası bağlantı problemi oluşmakta; kesite özgü farklılıkların ortaya çıkmasıyla değişen varyans ve tahmin edilen parametrelere ait varyanslar da büyük olmaktadır (Psillaki, and Daskalakis, 2009, s.328). Literatürde değişen varyans ve otokorelasyon sorunlarının söz konusu olduğu durumlarda sıklıkla tercih edilen iki farklı model bulunmaktadır. Bunlar, sırasıyla PraisWinsten modeli olarak da adlandırılan "Standart Hataları Düzeltilmiş Panel - Panel Corrected Standard Errors (PCSE)" yöntemi ve "Uygun Genelleştirilmiş En Küçük Kareler - Feasible Generalized Least Squares (FGLS)" yöntemidir. Beck ve Katz (1995 ve 1996), zaman boyutunun yatay kesit boyutundan küçük olduğu panel veri uygulamalarında PCSE'nin daha güvenilir bulgular verdiği göstermiştir. Bu nedenle, asimptotik $t$ istatistiklerinin kullanılamaması durumunda, dirençli $t$ istatistikleri elde etmek amacıyla, değişen varyans ve otokorelasyon problemlerini ortadan kald1ran ve Beck ve Katz (1995) tarafından geliştirilen Period Weights PCSE katsayı metodu uygulanarak düzeltme yapılmış ve model tahminine gidilmiştir. Model 1 için yapılan çift yönlü sabit etkiler tahmin sonuçlarına ilişkin elde edilen katsayı ve istatistikler Tablo-5'te özetlenmiştir.

Tablo 7. Model 3 Tahmin Sonuçlarn

\begin{tabular}{lllll}
\hline Değişkenler & Katsayı & Standart Hata & t istatistiği & Prob \\
\hline C & $-7,86868$ & 1,41422 & $-5,56398$ & 0,00000 \\
\hline D(HERD) & 5,83125 & 1,14192 & 5,10655 & 0,00000 \\
\hline SERMAYE & 0,32604 & 0,04688 & 6,95500 & 0,00000 \\
\hline POPG & $-1,35562$ & 0,33236 & $-4,07874$ & 0,00010 \\
\hline TICARET & 3,41269 & 0,97588 & 3,49704 & 0,00050 \\
\hline ENF & $-0,04789$ & 0,02015 & $-2,37618$ & 0,01790 \\
\hline D(EGITIM) & $-3,27826$ & 1,09828 & $-2,98490$ & 0,00300 \\
\hline & R-squared & 0,61531 & Mean dependent var & 2,02277 \\
\hline & Adjusted R-squared & 0,57514 & S.D. Dependent var & 3,44956 \\
\hline & S.E. of regression & 2,24848 & Akaike info criterion & 4,54963 \\
\hline & Sum squared resid & 2517,71800 & Schwartz criterion & 4,96437 \\
\hline & Log likelihood & $-1200,42200$ & Hannan-Quinn & 4,71169 \\
\hline & F-statistic & 15,31794 & Durbin-Watson stat & 1,18602 \\
\hline & Prob (F-statistic) & 0,00000 & & \\
\hline
\end{tabular}

Kamu kesiminin büyüme etkilerinin izlenebildiği Tablo-6'ya göre, kamu kesimi ar-ge yoğunluğu (GOVERD), SERMAYE ve TICARET'in KBB üzerindeki etkisi pozitif ve \%5 düzeyinde istatistiki olarak anlamll; 
POPG ve ENF'ninki ise, negatif ve \%5 düzeyinde anlamlıdır. EGITIM'in bağımlı değişken üzerindeki etkisi negatif ve \%5 düzeyinde istatistiki olarak anlamsız bulunmuştur. Belirlilik katsayısının anlamlı olduğu $\left(R^{2}=0,60\right)$ görülmektedir. F-istatistiği olasılık değerine göre de, tüm değişkenler istatistiki olarak anlamlıdır.

Yükseköğrenim kesiminin büyüme etkilerinin izlendiği Tablo-7'ye göre, yükseköğrenim ar-ge harcamalarının GSYİH'daki payı (HERD), SERMAYE ve TICARET değişkenlerinin KBB üzerindeki etkisi pozitif ve $\% 1$ düzeyinde istatistiksel olarak anlamli; POPG, ENF ve EGITIM'in etkileri ise, negatif ve $\% 5$ düzeyinde istatistiki olarak anlamlıdır. Belirlilik katsayısının anlamlı olduğu $\left(\mathrm{R}^{2}=0,62\right)$ görülmektedir. F-istatistiği olasılık değerine göre, tüm değişkenler istatistiki olarak anlamlıdır.

\section{Sonuç}

Ar-ge faaliyetleri ile büyüme arasındaki etkileşim, politika yapımında mutlaka dikkate alınması gereken nitelik ve önemdedir. Ar-ge harcamalarının özel, kamu ve yükseköğrenim kesimleri ayrımında incelenmesi, çıtı ve verimlilik üzerindeki etkilerin izlenebilmesini mümkün kılmakta; yenilik ve ar-ge politikalarından dolaylı ya da doğrudan etkilenen iktisadi aktörleri dikkate almaktadır. "Ar-ge harcamaları büyümeye pozitif yönde katkı sağlamaktadır" ön kabulü ve ana hipotezini fon kaynağı ayrıştırması bağlamında araştıran bu çalışmanın analiz bulguları, büyüme etkileri bakımından üniversiteler, özel kesim ve kamu şeklinde bir sıralamayı ortaya koymaktadır. Temel araştırmaları yürütme fonksiyonu ile yükseköğrenim kesiminin büyümeyi en fazla etkileyen kesim olarak ön plana çıkması, dikkatleri ar-ge işbirliklerinin pozitif dışsallıklarına yöneltmektedir. Bu çalışmada tartışılmayan ar-ge' nin dışsallık boyutunun başka araştırmalara konu edilmesi önerilir.

Bu gelişmeler doğrultusunda ele alınan çalışmada, ar-ge harcamalarının kişi başına GSYİH'nın büyüme oranı üzerindeki etkileri, fon kaynağ bakımından bir ayrıma tabi tutularak panel veri yöntemiyle araştırılmıştır. Analiz, ABD, Almanya, Avusturya, Belçika, Çek Cumhuriyeti, Danimarka, Estonya, Finlandiya, Fransa, Güney Kore, Hollanda, İngiltere, İrlanda, İspanya, İsveç, İtalya, İzlanda, Japonya, Kanada, Letonya, Macaristan, Meksika, Norveç, Polonya, Portekiz, Slovakya, Slovenya, Türkiye ve 
Yunanistan olmak üzere, 29 OECD ülkesinin 1996-2015 dönemi verilerini kullanmaktadır. "Ar-ge yoğunluğu ile kişi başına gelirin büyüme oranı arasında pozitif ve istatistiksel olarak anlamlı bir ilişki vardır" şeklindeki temel hipotez, panel veri yöntemiyle ve Çift Yönlü Sabit Etkiler tahmincisi kullanılarak sınanmıştır. Tahmin sonuçları, özel kesim, kamu ve yükseköğrenim ar-ge yoğunluğunun büyüme üzerinde pozitif ve yüksek oranlı bir etkisi olduğunu göstermektedir.

GSYİH'nın belirleyicileri olarak BERD, SERMAYE, POPG, TICARET, ENF ve EGITIM, değişkenlerinden yararlanan Model-1'in, 29 OECD ülkesi için 1996-2015 dönemi verileriyle yapılan analiz bulgularına göre, OECD ülkelerinin özel kesim ar-ge yoğunluğunda (BERD) meydana gelen \%1'lik artış, büyüme oranını \%2,61; GOVERD, SERMAYE, POPG, TICARET, ENF ve EGITIM, değişkenlerinden yararlanan Model-2'nin analiz bulgularına göre, kamu kesimi ar-ge yoğunluğunda (GOVERD) meydana gelen \%1'lik artış, büyümeyi \%1,84; HERD, SERMAYE, POPG, TICARET, ENF ve EGITIM, değişkenlerinden yararlanan Model-3'ün bulgularına göre, yükseköğrenim ar-ge yoğunluğunda (HERD) meydana gelen \%1'lik artış, büyümeyi $\% 5,83$ oranında arttırmaktadır. BERD, GOVERD ve HERD katsayılarının pozitif işaretli ve istatistiksel olarak anlamlı olması, teorik beklentilere uygun olarak özel kesim, kamu ve yükseköğrenim arge harcamalarıyla büyüme arasında pozitif bir ilişki olduğunu teyit etmektedir.

POPG ile EGITIM katsayıları negatif ve istatistiki olarak anlamlıdır. Bu durum, OECD bağlamında bir açıklamayı gerekli kılmaktadır. Nüfus artışı, teknolojik gelişme, beşeri sermaye ve gelir ilişkisini analiz eden Galor ve Weil'e (1999, s.152-153) göre, teknolojik gelişmenin nüfus artışı üzerinde iki yönlü etkisi vardır. Birinci etki, ailenin kaynak dağılımını çocuklarını iyi yetiştirmek üzere planlaması; ikinci etki ise, emeğin niteliklerinin gelişmesi sonucu beşeri sermaye birikiminin artmasıdır. Bu bağlamda, uzun dönemde beşeri sermaye birikiminin artması, teknolojik gelişme ve büyüme üzerinde olumlu etkiler yaratmaktadır. Nüfus artışı, büyümeyi negatif yönde etkiliyor gibi görünse de, beşeri sermayenin önemli bir bileşeni olması sebebiyle nüfustaki artışın, ar-ge ve büyüme arasındaki pozitif etkileşime dolaylı şekilde katkı sağladığı düşünülmektedir.

Fon kaynakları bakımından ar-ge'nin büyüme sonuçlarını ortaya koyması bakımından özgün nitelik taşıyan bu çalışmanın sonuçlarına göre 
büyümenin sürekliliği için, özel, kamu ve yükseköğrenim kesimlerince arge yatırımları arttırılmalı, teknoloji transferi sağlayan doğrudan yabancı yatırımlar teşvik edilmeli; üniversite ve özel kuruluşların ar-ge projeleri desteklenmelidir. Özel, kamu ve yükseköğrenim kesimleri arasında işbirlikleri tesis edilerek sosyal, iktisadi ve çevresel sorunlara uyumlu ar-ge politikaları geliştirilmelidir. Kamu ve özel kesim ile üniversiteler arasında tesis edilen bilim ve teknoloji ortaklıkları, ülkelerin sosyal ve küresel değişikliklere adaptasyon başarısını arttırmaktadır. Özel sektörün finansal sınırlılıklarını ortadan kaldıracak mali teşvikler ve vergi muafiyetleri arttırılmalı; ar-ge faaliyetlerini arttırmaya yönelik hukuki düzenlemelere gidilmelidir. Kamu araştırma kurumları ve fon programları geliştirilmeli; ar-ge çıtıları ticarileştirilmelidir. Doğrudan yabancı yatırımların önündeki engeller azaltılarak sınır ötesi bilgi transferinin önü açılmalıdır. Analiz bulgularına dayalı olarak elde edilen katsayı büyüklükleri düşünüldüğünde, önerilen politika düzenlemelerinin ülke ekonomilerine katkı sağlayarak büyümeyi hızlandıracağı düşünülmektedir. 


\section{EXTENDED ABSTRACT}

\section{R\&D Activities of Public and Private Sector and Economic Growth: The Case of OECD

\author{
Yusuf Bayraktutan - Fatma Kethudaoğlu \\ The Scientific And Technological Research Council Of Turkey, Kocaeli University
}

Research and development (R\&D) activities affect competitiveness, foreign trade and growth performance through technological development; the difference in the share of national income allocated to R\&D activities separates countries economically. Developed countries devotes more resources to R\&D which result in innovation, new products/methods; low unit costs, increased quality and competitiveness supporting growth performance.

The concept of R\&D has taken its place in the literature as a measure of technological development and innovation in parallel with theoretical efforts to explain long-term growth. R\&D, information, and processes embodied in the existing physical and human resources lead to effective use and activities that bring out new technologies. In the Frascati Guideline, which has been prepared by OECD to determine a standard measure, systematic and creative studies on increasing the stock of information and using it to design new applications are called R\&D. Obtaining new technical knowledge in order to eliminate uncertainties in scientific and technological fields, developing new production methods and processes, production of new techniques and prototypes with design, cost-effectiveness of a product, researching new techniques and technologies that improve quality or performance, and software activities based on original design. As a result of $R \& D$, a new product may emerge, and the possibility of producing existing products at a lower cost may arise. When the products obtained as a result of $R \& D$ activities become marketable, the $R \& D$ project is completed.

Based on the idea that there is a positive interaction between R\&D activities carried out by private, public and higher education sectors, this study first includes theoretical knowledge reflecting the place of R\&D and technological development in economic thought; secondly, the technology 
and R\&D policies of OECD countries were evaluated. In this direction, the main hypothesis "There is a positive and statistically significant relationship between R\&D intensity and growth rate of per capita income was tested; R\&D, private sector, public sector and higher education expenditures according to the source of funding; the effects of R\&D expenditures on the gross domestic product (GDP) are evaluated by the funding source. The analysis was limited to 29 OECD countries and 1996-2015 period, and the Panel Data Regression Model was used.

In this study, the effects of $R \& D$ expenditures on the growth rate of GDP per capita were investigated by panel data method. Data from 29 OECD countries including Austria, Belgium, Czech Republic, Denmark, Estonia, Finland, France, Germany, Iceland, Italy, Japan, Latvia, Hungary, Italy, Japan, Latvia, Netherlands, Spain, Sweden, United Kingdom, United States Poland, Portugal, Slovakia, Slovenia, Turkey and Greece for 1996-2015 period were used. The basic hypothesis that "There is a positive and statistically significant relationship between $R \& D$ intensity and growth rate of per capita income was tested by using panel data method and Bidirectional Fixed Effects estimator. Estimation results show that private, public and higher education R\&D intensity has a positive and high rate of impact on growth.

The interaction between $R \& D$ activities and growth is of importance to be considered in policy making. The analysis of R\&D expenditures in terms of private, public and higher education makes it possible to monitor the effects on output and productivity; takes into account the economic actors directly or indirectly affected by innovation and R\&D policies. R\&D spending contributes positively to growth in the context of preliminary acceptance and the main hypothesis in terms of funding source decomposition. The fact that higher education sector has the most impact on growth with the function of conducting basic research leads attention to positive externalities of R\&D collaborations. It is recommended that the externality dimension of $R \& D$ should be the subject of other studies.

According to the results of this study, which is unique in terms of revealing the results of $R \& D$ growth in terms of funding sources, R\&D investments should be increased by private, public and higher education sectors and direct foreign investments providing technology transfer 
should be encouraged, R\&D projects of universities and private institutions should be supported.

R\&D policies compatible with social, economic and environmental problems should be developed by establishing cooperation between private, public and higher education sectors. Science and technology partnerships established between public and private sectors and universities increase the success of countries to adapt to social and global changes. Increase financial incentives and tax exemptions to eliminate the financial limitations of the private sector; legal arrangements should be made to increase R\&D activities. Public research institutions and funding programs should be developed; R\&D outputs should be commercialized. Barriers to foreign direct investment should be reduced and cross-border information transfer should be paved. Considering the coefficient sizes obtained, it has been thought that the proposed policy arrangements will accelerate growth by contributing to the national economies.

\section{Kaynakça / References}

Aghion, P. ve Howitt, P. (1992). A model of growth through creative destruction. Econometrica, 60(2), 323-352.

Aghion, P. ve Howitt, P. (1998). Endogenous growth theory. Cambridge: MIT Press.

Arrow, K. J. (1962). The Economic implications of learning by doing. The Review of Economic Studies, 29(3), 155-173.

Baltagi, B. H. (2008). Econometric analysis of panel data. England: John Wiley\&Sons.

Barro, R. J. (1990). Government spending in a simple model of endogeneous growth. The Journal of Political Economy, 98(5), 103-125.

Bassanini, A. ve Scarpetta, S. (2001). The driving forces of economic growth: Panel data evidence for the OECD countries. OECD Economic Studies, 33(2001/II), 9-56.

Bayraktutan, Y. ve Bıdırdı, H. (2016). Teknoloji ve rekabetçilik: Temel kavramlar ve endeksler bağlamında bir değerlendirme. Akademik Araştırmalar ve Çalışmalar Dergisi, 8(14), 1-24.

Bayraktutan, Y. ve Kethudaoğlu, F. (2017). Ar-Ge ve iktisadi büyüme ilişkisi: OECD örneği. Uluslararası Sosyal Araştırmalar Dergisi, 10(53), 679-694. 
Beck, N. ve Katz, J. N. (1995). What to do (and not to do) with time series cross-section data. The American Political Science Review, 89(3), 634-647.

Beck, N. and Katz, J. N. (1996). Nuisance vs. substance: Specifying and estimating time-series-cross-section models. Political Analysis, 6, 1-36.

Blanco, L., Prieger, J. ve Gu, J. (2013). The Impact of research and development on economic growth and productivity in the US States. Pepperdine University School of Public Policy Working Paper Series, No: 48.

Bucci, A. (2005). Product market competition, RED effort and economic growth, UNIMI - Research Papers in Economics, Business and Statistics, Milano: Universitá degli Studi di Publications.

Eaton, J. ve Kortum, S. (1994). International patenting and technology diffusion. NBER Working Paper Series, No: 4931.

Falk, M. (2007). R\&D spending in the high-tech sector and economic growth. Research in Economics, 61, 140-147.

Fine, B. (2000). Endogenous growth theory: A critical assessment. Cambridge Journal of Economics, 24(2), 245-265.

Galor, O. ve Weil, D. N. (1999). From malthusian stagnation to modern growth. The American Economic Review, 89(2), 150-154.

Goel, R. K., ve Ram, R. (1994). Research and development expenditures and economic growth: A cross- country study. Economic Development and Cultural Change, 42(2), 403-411.

Goel, R. K., Payne, J. E., ve Ram, R. (2008). R\&D expenditures and U.S. economic growth: A disaggregated approach. Journal of Policy Modelling, 30(2), 237-250.

Göçer, İ., Alataş, S. ve Peker, O. (2016). Effects of R\&D and innovation on income in EU Countries: New generation panel cointegration and casuality analysis. Theoretical and Applied Economics, 4(609), 153-164.

Grossman, G. M., ve Helpman, E. (1991). Quality ladders in the theory of growth. Review of Economic Studies, 58, 43-61.

Guellec, D., ve Potterie, V. P. B. (2001). R\&D and productivity growth: Panel data analysis of 16 OECD countries. OECD Economic Studies, 33, 103126.

Griffith, R. (2000). How important is business RED for Economic growth and should the goverment subsidise it?, London: The Institute for Fiscal Studies Publications. 
Gyekye, A. B., Oseifual, E. K., ve Quarshie, G. N. K. V. (2012). The impact of research and development on socio-economic development: Perspectives from selected developing economies. Journal of Emerging Trends in Economics and Management Sciences, 3(6), 915-922.

Hsiao, C. (2003). Analysis of panel data. Cambridge: Cambridge University Press.

Im, K. S., Pesaran, H. M., ve Shin, Y. (2003). Testing for unit root in heterogeneous panels. Journal of Econometrics, 115(1), 53-74.

Jesus, M., ve Seren, F. (1999). Aggregate R\&D expenditure and endogenous economic growth. UFAE and IAE Working Papers, No: 436-99.

Khan, M., Luintel, K. B., ve Theodoridis, K. (2010). How robust is the r\&dproductivity relationship? Evidence from OECD Countries. WIPO Economic Research Working Paper Series, No: 1.

Levin, A., Lin, C. F., ve Chu, C. S. J. (2002). Unit root tests in panel data: Asymptotic and finite-sample properties. Journal of Econometrics, 108(1), 1-24.

Lichtenberg, F. R. (1993). R\&D investment and international productivity differences. NBER Working Paper Series, No: 4161.

Lucas, R. E. (1988). On the mechanics of economic development. Journal of Monetary Economics, 22, 3-42.

Marx, K. (2003). Kapital I, (Çev. A. Bilgi), İstanbul: Eriş Yayınları.

OECD (1993). Frascati manual 1993: The measurement of scientific and technological activities: proposed standard practice for surveys of research and experimental. Paris: OECD Publications.

OECD (2002). Dynamising national innovation systems. Paris: OECD Publications.

OECD (2004). Science, technology and industry outlook 2004. Paris: OECD Publications.

OECD (2008). Policy responses to the economic crisis: Investing in innovation for long - term growth. OECD Policy Brief, Paris: OECD Publications.

OECD (2010a). Measuring innovation: A new perspective. Paris: OECD Publications.

OECD (2010b). OECD Science, technology and industry outlook 2010. Paris: OECD Publications.

OECD (2011a). OECD Reviews of regional innovation, regions and innovation policy. Paris: OECD Publications. 
OECD (2011b). Factbook - economic, environmental and social statistics. Paris: OECD Publications.

OECD (2013). "RED tax incentives", in OECD science, technology and industry scoreboard 2013: Innovation for growth. Paris: OECD Publications.

OECD (2014a). Expert consultation on the silver economy: facts, challenges and opportunities. Directorate for science, technology and industry committee on digital economy policy. United Kingtom: Oxford Publications.

OECD (2014b). Science, technology and industry outlook 2014. Paris: OECD Publications.

OECD (2017). Science, technology and innovation database. 18.04.2017 tarihinde www.oecd.org/ adresinden erişilmiştir.

Park, W. G. (1995). International R\&D spillovers and OECD economic growth. Economic Inquiry, 33(4), 571-591.

Poorfaraj, A., SAMIMI, A. J., ve Keshavarz, H. (2011). Knowledge and economic growth: Evidence from some developing countries. Journal of Education and Vocational Research, 1(1), 21-25.

Psillaki, M., ve Daskalakis, N. (2009). Are the determinants of capital structure country or firm specific? Small Busssiness Economy, 33, 319-333.

Rensman, M. (1996). Economic growth and technological change in the long run: A survey of theoretical and empirical literature. 21.12.2015 tarihinde http://www.rug.nl/research/portal/files/3247240/96c10.pdf/ adresinden erişilmiştir.

Ricardo, D. (1817). On the principles of political economy and taxation. Kitchener: Batoche Books.

Romer, P. (1986). Increasing returns and long - run growth. The Journal of Political Economy, 94(5), 1002-1037.

Romer, P. M. (1990). Endogenous technological change. Journal of Political Economy, 98(5), 71-102.

Romer, Paul M. (1994). The origins of endogenous growth. Journal of Economic Perspectives, 8(1), 3-22.

Sadraoui, T., A., Tarek, B., ve Deguachi, B. (2014). Testing for panel granger casuality relationship between international R\&D cooperation and economic growth, International Econometrics and Financial Management, 2(1), 7-21.

Schumpeter, J. A. (2003). Capitalizm, socialism and democracy. Taylor \& Francis e-Library. 09.05.2016 tarihindehttp://digamo.free.fr/capisoc.pdf/ adresinden erişilmiştir. 
Smith, Adam (1776). An inquiry into the nature and causes of the wealth of nations - An electronic classics series publication, (Ed. J. Manis), Pennsylvania: The Pennsylvania State University.

Solow, R. M. (1956). A contribution to the theory of economic growth. The Quarterly Journal of Economics, 70(1), 65-94.

Tang, S., Hu, Z., ve Lin, Y. (2005). Knowledge as production factor: Toward a unified theory of economic growth. Journal of Evolutionary Economics, 2005, 1-68.

UNESCO (2010). Measuring RED: Challenges faced by developing countries. Technical Papers, No: 5.

UNESCO (2016). UNESCO Science report - towards 2030. New York: United Nations Publications.

Ülkü, H. (2004). RED, innovation, and economic growth: An empricial analysis, IMF Working Paper Series, No. 04/185.

Wooldridge, J. M. (2002). Econometric analysis of cross section and panel data. Cambridge: MIT Press.

World Bank (2019). Statistical database. 09.12.2019 tarihinde https://data.worldbank.org/topic/science-and-technology adresinden erişilmiştir.

UNESCO (2019). Statistical database. 09.12.2019 tarihinde http://data.uis.unesco.org/Index.aspx?DataSetCode=scn_ds adresinden erişilmiştir.

\section{Kaynakça Bilgisi / Citation Information}

Bayraktutan, Y. ve Kethudaoğlu, F. (2019). Kamu ve özel sektör ar-ge faaliyetleri ve iktisadi büyüme: OECD örneği. OPUS-Uluslararası Toplum Araştırmaları Dergisi, 14(20), 1594-1625. DOI: 10.26466/ opus.581612 